\title{
ANALISIS SMA NEGERI BERPRESTASI DIBIDANG EKSTRAKURIKULER FUTSAL KOTA BENGKULU
}

\author{
Faisal Mandala Siregar \\ Yarmani \\ Universitas Bengkulu \\ Bogy Restu Ilahi \\ Universitas Bengkulu
}

PENJAS FKIP UNIB, e-mail: : Faizalmsiregar@gmail.com

\begin{abstract}
Abstrak
Penelitian ini bertujuan untuk mengetahui prestasi ekstrakurikuler futsal. Metode yang digunakan adalah metode penelitian deskriptif. Subjek penelitian adalah 9 Sekolah Menengah Atas Negeri di Kota Bengkulu. Instrumen dari penelitian ini yaitu Observasi, Kuesioner, dan Dokumentasi. Hasil penelitian menunjukuan persentase perkembangan ekstrakurikuler futsal ditingkat SMA Negeri kota Bengkulu berkembang 5 sekolah 55,55\%, belum berkembang 4 sekolah $44,44 \%$. Setelah mendapatkan persenan data maka dapat perbandingan perkembangan ekstrakurikuler futsal ditingkat SMA N kota Bengkulu 5:4, adalah berkembang. Berdasarkan perolehan data perkembangan estrakurikuler futsal ditingkat SMA Negeri Kota Bengkulu harus memperhatikan indikator yang baik seperti pelatih berkompeten, manajemen yang baik, fasilitas, metode latihan dan prestasi. Maka hasil data diperoleh dari sembilan sekolah ada 5 sekolah yang memiliki indikator yang baik. Sedangkan 4 sekolah dinyatakan belum ada perkembangan terlihat dari indikator yang belum memenuhi proses menunjangnya perkembangan ekstrakurikuler futsal.
\end{abstract}

Kata kunci : SMA, Negeri, Berprestasi.

\begin{abstract}
This study aims to determine the futsal extracurricular achievement. The method used is descriptive research method. Research subjects are 9 State Senior High Schools in Bengkulu City. Instruments of this research are Observation, Questionnaire, and Documentation. The result of research shows that the percentage of extracurricular futsal development at the level of Upper Secondary School of State of Bengkulu grew by 5 schools 55.55\%, not yet developing 4 schools $44.44 \%$. After getting the data percentage then can comparison of extracurricular futsal development at Bengkulu 5: 4 High School level, is growing. Based on data acquisition of futsal estrakurikuler developments at State Senior High School of Bengkulu City should pay attention to good indicators such as competent trainers, good management, facilities, training methods and achievements. So the results of data obtained from nine schools there are 5 schools that have good indicators. While 4 schools stated there has been no visible development of indicators that have not fulfilled the process of supporting the development of extracurricular futsal.
\end{abstract}

Keywords: Development, Extracurricular, Futsal. 


\section{PENDAHULUAN}

Futsal merupakan olahraga menarik dan dinamis, hal ini dikarenakan selama permainan futsal berlangsung bola selalu bergulir cepat dari kaki ke kaki. Tipe permainan yang menjadi ciri khas olahraga futsal adalah adanya situasi yang berubah secara konstan. Pada saat ini olahraga futsal banyak digemari oleh semua kalangan mulai dari anak-anak, remaja, hingga orang tua, baik laki-laki maupun perempuan. Olahraga futsal ini mulai digemari dikarenakan kurangnya minat olahraga sepak bola di Indonesia. Hal ini terjadi akibat kurang tersedianya lapangan sepak bola di kota-kota besar. Faktor lainya yang meningkatkan minat olahraga futsal, yaitu dengan semakin banyak GOR lapangan futsal di lapangan daerah kota. Futsal memiliki peraturan yang berbeda dengan sepak bola, peraturan futsal cenderung tegas tentang kontak fisik. Seperti yang dijelaskan Lhaksana dan Pardosi (2008: 33) bahwa:

("Futsal adalah suatu jenis olahraga yang memilki aturan tegas tentang kondisi fisik. Sliding tackle (menjegal dari belakang), body charge (benturan badan), dan aspek kekerasan lain, seperti dalam permainan sepak bola tidak diizinkan dalam futsal.")

Lhaksana (2011: 5) mengatakan bahwa "Permainan futsal cenderung lebih dinamis karena gerakan yang cepat. Dalam permainan futsal, pemain harus memilki teknik dasar yang mumpuni, seperti; mengumpan (passing), menerima (receiving), mengumpan lambung (chipping), menggiring (dribbling), menembak (shooting), dan menyundul (heading). Futsal olahraga beregu yang harus memiliki kekompakan yang baik. Oleh karena itu dibutuhkan kerja sama dalam tim untuk mencapai prestasi tertinggi dalam sebuah tim futsal. Adapun yang dijelaskan Lhaksana (2011: 7) mengatakan bahwa "Menang dan kalah itu terjadi diseluruh olahraga, tetapi if you die, you die with honour. Tidak ada pemain yang paling berjasa dalam satu tim, yang ada adalah tim yang baik akan menjadikan seseorang pemain mejadi bintang.

Berkembangnya kegiatan ektrakurikuler futsal di SMA $\mathrm{N}$ kota Bengkulu perlu mendapatkan perhatian yang khusus, diantaranya pembinaan kegiatan ekstrakurikuler itu sendiri. Terkhusus pada SMA N 3, SMA N 7, SMA N 8 dan SMA N 10 perlu medapat sorotan lebih ekstrakurikkuer futsal yang memiliki prestasi futsal yang baik dibandikan SMA $\mathrm{N}$ lain di kota Bengkulu. Adanya pembinaan yang baik ekstrakurikuler futsal disetiap SMA N kota Bengkulu dapat berkembang, dan menjadikan tim futsal SMA N kota Bengkulu memiliki kualitas dan skill yang dimiliki tim bisa bersaing. Sehingga akan terlihat disetiap turnamen futsal antar pelajar setiap tim futsal antar SMA $\mathrm{N}$ bisa mendapatkan peluang menjadi pemenang. Adanya pembinaan yang baik, kualitas tim yang sama rata menjadikan ekstrakurikuler futsal ditingkat SMA N kota Bengkulu semakin banyak diminati dan berkembang. Kelemahan-kelemahan suatu pembinaan ekstrakurikuler futsal, antara lain terletak pada ada atau tidaknya dukungan penuh dari sekolah itu sendiri, konsistensi latihan yang dibentuk, dan pembiayaan anggaran kebutuhan ekstrakurikuler futsal.

Dengan demikian penulis tertarik untuk penelitian dengan judul : "Analisis SMA Negeri Berprestasi Dibidang Ekstrakuriler Futsal Kota Bengkulu." 


\section{METODE}

Sesuai dengan permasalahan dan tujuan penelitian yang telah diuruaikan sebelumnya, bahwa penelitian yang dimaksud adalah tentang SMA Negeri berprestasi dibidang ekstrakurikuler futsal kota Bengkulu. Jenis penelitian ini adalah penelitian lapangan yang bersifat deskriptif analisis yang menggunakan pendekatan kualitatif. Deskriptif adalah hanya ini menggambarkan situasi yang sedang berlangsung, tanpa penguji hipotesis. Sugiyono (2006: 6) menyatakan bahwa metode survey digunakan untuk mendapatkan data dari tempat tertentu yang alamiah (bukan buatan), tetapi peneliti melakukan perlakuan dalam pengumpulan data, misalnya dengan mengedarkan kuesioner, tes, wawancara intsruktur dan sebagainya.

Tempat penelitian ini dilakukan di SMA $N$ kota Bengkulu. Penelitian dilakukan selama 1 bulan terhitung sejak dikeluarkannya surat izin meneliti hingga batas waktu yang ditentukan. Subyek Penelitian Mengambil subyek dalam penelitian ini menggunakan teknik purposive, yaitu dengan memilih orangorang yanng diangggap tahu tentang fokus masalah seperti pihak yang terkait dengan pengambilan keputusan seperti pelatih. Kemudian dipadukan dengan teknik snowball sampling, yaitu meminta informan sebelumnya untuk menunjukan orang-orang yang dapat dijadikan informan. Sugiyono (2006: 246).

Obyek penelitian ini mengambil
obyek penelitian seluruh yang
berhubungan dengan prestasi
ekstrakurikuler futsal SMA Negeri di kota
Bengkulu. Menurut Sanafiah Faisal dalam
Sugiyono (2006: 328) dalam mengambil
subyek dan obyek penelitian harus yang

memahami dan yang tergolong masih berkecimpung atau terlibat dalam kegiatan yang akan diteliti. Instrumen penelitian dalam penelitian ini adalah peneliti sendiri. Instrumen penelitian adalah angket terbuka. Studi Dokumentasi. Keabsahan data penelitian Menurut Sugiyono (2006: 271) menggunakan triangulasi teknik yaitu menguji kredibilitas data dengan cara mengecek data kepada sumber yang sama dengan teknik yang berbeda. Seperti data yang diperoleh dari observasi, lalu di cek dengan kuesioner, dokumentasi. Teknik analisis data merupakan hal yang sangat penting dalam penelitian karena analisis data dapat memberi arti makna yang berguna dalam memecahkan masalah penelitian Aktivitas dalam analisis data yaitu: data reduction, data display, dan conclusion.

\section{HASIL DAN PEMBAHASAN Hasil}

Penelitian Analisis ini dilakukan di SMA Negeri kota Bengkulu dengan melakukan penelitian dengan menggunakan observasi, kuesioner kepada responden yang berhubungan dengan prestasi ekstrakurikuler futsal kota Bengkulu. Dalam penelitian ini data kuesioner yang diperoleh dilapangan jumlahnya cukup banyak, untuk itu perlu dicatat secara teliti dan rinci lalu dirangkum memilih hal-hal yang pokok, memfokuskan pada hal-hal yang penting. Berdasarkan hasil kuesioner yang sudah dirangkum, memilih hal-hal yang pokok, memfokuskan pada hal-hal yang penting, dicari tema dan polanya dan membuang yang tidak perlu, dapat ditarik kesimpulan prestasi ekstrakurikuler futsal SMA Negeri di kota Bengkulu masih banyak yang perlu diperhatihan oleh pihak sekolah tersebut. Pelatih yang kurang berkompeten terlihat 
dari lisensi kepelatihan yang diprolehnya, dan ketersedian fasilitas perlengkapan yang belum sama rata ada yang memiliki lapangan yang bagus, bola yang banyak, dan ada juga yang tidak. Ketidak rataan dari segi pembinaan, pelatih dan fasilitas perlengkapan yang membuat semua SMA $\mathrm{N}$ kota bengkulu memiliki perbedaan dari prestasi ekstrakurikuler futsal tersebut. Hambatan dalam perkembangan adalah dukungan pihak sekolah, pembinaan ekstrakurikuler, dan pelatih ekstrakurikuler futsal.

Berdasarkan has

il keseluruhan yang mencangkup kajian teori 5 sekolah yang dinyatakan berkembang yaitu SMA N 1 kota Bengkulu, SMA N 2 kota Bengkulu, SMA N 4 kota Bengkulu, SMA N 5 kota Bengkulu, dan SMA N 6 kota bengkulu, 4 sekolah tidak memenuhi komponen-komponen yang mendukung ekstrakurikuler futsal berkembang yaitu SMA $\mathrm{N} 3$ kota Bengkulu, SMA N 7 kota Bengkulu, SMA N 8 kota Bengkulu, dan SMA N 10 kota Bengkulu. Hasil penelitian menunjukuan persentase perkembangan ekstrakurikuler futsal ditingkat SMA $N$ kota Bengkulu berkembang 5 sekolah $55,55 \%$, belum berkembang 4 sekolah $44,44 \%$. Setelah mendapatkan persenan data maka dapat perbandingan perkembangan prestasi ekstrakurikuler futsal ditingkat SMA $\mathrm{N}$ kota Bengkulu 5:4, adalah berkembang.

Display dari hasil data yang diproleh, perkembangan ekstrakurikuler futsal ditingkat SMA $\mathrm{N}$ kota Bengkulu memperoleh 5 SMA $\mathrm{N}$ kota Bengkulu memiliki dukungan sekolah, pembinaan ekstrakurikuler, fasilitas perlengkapan, pelatih futsal yang berkompeten dan terstruktur. Sedangkan 4 SMA N kota Bengkulu lainnya belum memenuhi kriteria sekolah yang terstruktur dan berkompeten dalam bidang kegiatan ekstrakurikuler futsal. SMA $\mathrm{N}$ kota Bengkulu masih ada yang belum bisa memenuhi kriteria sekolah yang terstruktur dan berkompeten dalam bidang ekstrakurikuler futsal.

Conclution drawing/ verification kesimpulan dari data display kembali dengan penelitian kembali ke lapangan mengumpulkan data, menemui sumber data dan mengklarifikasi kesimpulan kepada sumber data yang telah memberikan informasi.

\section{Pembahasan}

Berdasarkan prosedur penelitian yang dirancang dan dilaksanakan dengan sistematis dan terencana dengan baik, maka peneliti dapat mengumpulkan datadata penelitian yang merupakan informasi penting hasil penelitian seperti yang disajikan dalam deskripsi penelitian diatas. Penelitian bertujuan untuk mengetahui perkembangan ekstrakurikuler futsal, penelitian ini menggunakan metode penelitian deskriptif kualitatif. Pada deskripsi data mengenai "Analisis Perkembangan Ekstrakurikuler Futsal Ditingkat SMA N Kota Bengkulu", maka dapat dikemukakan jawaban rumusan masalah yang telah diajukan sebelumnya yaitu "Bagaimanakah perkembangan ekstrakurikuler futsal ditingkat SMA N kota Bengkulu?". Untuk lebih jelasnya jawaban dari pertanyaan dapat diuraikan sebagai berikut :

Berdasarkan hasil data diperoleh dari 9 sekolah ada 5 sekolah yang dapat dinyatakan sekolah yang memiliki ekstrakurikuler futsal yang berkembang yaitu SMA N 1, SMA N 2, SMA N 4, SMA N 5, SMA N 6. Empat sekolah dinyatakan masih belum berkembang diantaranya SMA N 3, SMA N 7 SMA N 8 SMA N 10. Berdasarkan hasil penelitian tersebut dapat disimpulkan bahwa sekolah 
berkembangan 5 sekolah 55,55\%, 4 sekolah belum berkembang 44,44\%. Banyak faktor-faktor yang mendukung perkembangan yaitu pembinaan yang bagus, dukungan dari pihak sekolah, memiliki pelatih yang berkompeten, memiliki fasilitas peralatan yang memadai dan memiliki target yang jelas. Maka dari itu hanya 5 sekolah SMA N kota Bengkulu yang dinyatakan berkembang. Sedangkan ke-4 sekolah SMA N kota Bengkulu belum bisa dikatakan berkembang disebabkan oleh tidak terpenuhinya faktor-faktor tersebut.

Membandingkan dengan kajian yang relevan hasil kesimpualan tingkat keterampilan teknik dasar bermain futsal peserta ekstrakurikuler futsal SMA dan SMK yayasan piri daerah itimewah yogyakarta tahun ajaran 2013. Penelitian ini membahas bahwa penelitian tentang tingkat keterampilan teknik dasar bermain futsal peserta ekstrakurikuler futsal sma dan SMK Yayasan Piri daerah istimewa Yogyakarta yang berjumlah 52 peserta, diantaranya 19 orang siswa SMA, 15 orang siswa SMK PIRI Yogyakarta dan 18 orang siswa SMK PIRI Sleman. Dapat dilihat dibawah ini termasuk dalam katagori cukup dikarenakan reratanya 76,96. Berdasarkan perhitungan di atas tingkat keteramilan teknik dasar bermain futsal peserta ekstrakurikuler futsal SMA dan SMK Yayasan PIRI Daerah Istimewa Yogyakarta, menunjukkan bahwa pemain yang masuk kategori baik sekali 0 pemain atau sebesar (0\%), kategori baik 15 pemain atau sebesar (28,8\%), kategori cukup 26 pemain atau sebesar (50,0\%), kategori kurang 5 pemain atau sebesar $(9,6 \%)$, kategori kurang sekali 6 pemain atau sebesar $(11,5 \%)$.

Membandingkan kedua kajian relevan manajemen ekstrskurikuler futsal sma negeri 4 yogyakarta tahun ajaran
2015. Menyimpulkan bahwa penerapan manajemen ekstrakurikuler futsal SMA Negeri 4 Yogyakarta yang terdiri dari perencanaan, pengorganisasian, penggerakan dan pengawasan telah dilakukan oleh pelatih kepala ekstrakurikuler futsal SMA Negeri 4 Yogyakarta dengan baik. Hasil penelitian menyimpulkan bahwa penerapan fungsifungsi manajemen ekstrakurikuler futsal SMA Negeri 4 Yogyakarta adalah perencanaan berjalan sesuai harapan pelatih kepala, pengorganisasian tidak ada tumpang tindih dalam proses pelaksanaan tugas, penggerakan sesuai instruksi pelatih kepala, pengawasan standar pelatihan dan hasil dari latihan tetap terjaga.

Dari kedua hasil penelitian yang pernah dilakukan, hasil penelitian yang penulis lakukan dapat memberikan perbandingan perkembangan futsal dari pembinaan, manajemen, sarana dan prasarana, metode latihan, prestasi, serta pelatih. Penelitian tingkat keterampilan teknik dasar bermain futsal peserta ekstrakurikuler futsal sma dan SMK Yayasan Piri daerah istimewa Yogyakarta memiliki kesamaan pelatih dalam pemberian pengetahuan, pengalaman, saat melakukan latihan ekstrakurikuler futsal. dalam penelitian manajemen ekstrskurikuler futsal sma negeri 4 yogyakarta tahun ajaran 2015 memiliki manajemen perancanaan, pengorganisasian dengan baik.

Pelatih yang berkompeten
memberikan perasan dari semua kemajuan suatu kegiatan ekstrakurikuler futsal disetiap Sekolah. Pembahasan mengenai bagaimanakah perkembangan ekstrakuurikuler futsal ditingkat SMA N kota Bengkulu dengan sudah sangat baik dari fokus masalah indikator pelatih, 
manajemen, prestasi, sarana dan prasarana dan metode latihan. Maka dapat dibuat dalam bentuk persentase melalui perhitungan rata-rata frekuensi. Hasil data persentase rata dikategorikan berkembang sesuai dengan hasil dari sembilan SMA Negeri kota Bengkulu 5 dikategorikan berkembang 4 dikategorikan tidak berkembang.

Hasil dari penelitian tersebut dapat diinterprestasikan bahwa ada beberapa faktor yang dapat mempengaruhi berkembang atau tidak berkembangnya perkembangan ekstrakurikuler futsal ditingkat SMA N kota Bengkulu yaitu :

1. Kurangnya dukungan dari pihak sekolah, sehingga fasilitas perlengkapan untuk kebutuhan pelatih melatih kurang efesien, lapangan yang berlobang, dan bola saat latihan kurang menjadikan program latihan tidak maksimal.

2. Pelatih yang tidak memiliki lisensi kepelatihan, serta memiliki perbedaan dari segi prestasi dan pengalaman melatih dengan pelatih yang memiliki lisensi kepelatihan. Sehingga membuat program latihan yang diterapkan kurang baik untuk peningkatan prestasi siswa. Ada yang menerapkan program latihan rutin, pengetahuan teori latihan yang luas, dan dapat mempraktekkan setiap teori yang berikan.

Komponen tersebut terpenuhi sangat mempengaruhi berkembangnya prestasi futsal disuatu SMA Negeri kota Bengkulu.

\section{PENUTUP}

\section{Simpulan}

Berdasarkan perolehan data prestasi estrakurikuler futsal ditingkat SMA Negeri Kota Bengkulu harus memperhatikan indikator pelatih, manajemen, fasilitas, metode latihan dan prestasi. Tanpa pelatih yang berkompeten seperti, merancang, menyusun, melaksanakan dan mengevaluasi proses berlangsungnya latihan perkembangan tidak dapat terbentuk. Adapun peranana dari manajemen yaitu memiliki dukungann yang penuh serta dapat memberikan fasilitas demi menciptakan keaktivan dan kedisiplinan siswa dalam melakukan latihan ekstrakurikuler futsal. Berdasarkan hasil data diperoleh dari sembilan sekolah ada 5 sekolah yang memiliki indikator yang baik. Sedangkan 4 sekolah dinyatakan belum ada perkembangan terlihat dari indikator yang belum memenuhi proses menunjangnya perkembangan prestasi ekstrakurikuler futsal. Berdasarkan hasil penelitian tersebut dapat disimpulkan bahwa perkembangan 5 sekolah tersebut disebabkan banyak indikator yaitu pembinaan yang bagus, dukungan dari pihak sekolah, memiliki pelatih yang berkompeten, memiliki fasilitas peralatan yang memadai dan memiliki target yang jelas. Maka dari itu hanya 5 sekolah SMA Negeri kota Bengkulu yang dinyatakan berkembang. Sedangkan ke-4 sekolah SMA Negeri kota Bengkulu belum bisa dikatakan berkembang disebabkan indikator yang menunjang proses perkembangan masih belum terpenuhi.

\section{Saran}

Setelah melakukan penelitian tentang "Analisis SMA Negeri Berprestasi Dibidang Ekstrakurikuler Futsal Kota Bengkulu", maka penulis memberikan saran-saran sebagai berikut: Perlu dukungan dari pihak sekolah sehingga fasilitas perlengkapan latihan pada ekstrakurikuler futsal ditingkat SMA $\mathrm{N}$ kota Bengkulu memadai. Sebaiknya setiap pelatih dari semua SMA N kota Bengkulu memiliki 
sertifikat pelatih yang berlisensi, karena mempengaruhi kualitas latihan yang diberikan pada siswa.

\section{DAFTAR PUSTAKA}

Amal A.A. 2005. Mengembangkan Kreatifitas Anak. Jakarta : Pustaka Al-Kautsar.

Anwar, Dessy. 2003. Kamus Lengkap Bahasa Indonesia Terbaru. Surabaya : Amelia Surabaya.

Charim, dkk. 2011. Mengenal Lebih Jauh Tentang Futsal. Jakarta : Multi Kreasi Satudelapan.

Lhaksana \& Pardosi. 2008. Inspirasi dan Spirit Futsal. Jakarta : Raih Asa Sukses.

Lhaksana, Justinus. 2011. Taktik \& Strategy Futsal Modern. Jakarta : Be Champion.

Mulyono, Muhammad Asriady. 2014. Buku Pintar Panduan Futsal. Banda Aceh: Laskar Aksara.

Sumarna Mumuh. 2006. Perbandingan Antara Siswa Yang Menjadi Pengurus Dan Bukan Pengurus OSIS Dalam Pemanfaatan Waktu Luang Dan

Prestasi Belajar di SMK N 6 Bandung. Skripsi Pada UPI Bandung: tidak diterbitkan.

Pamungkas, Yoga D.S. 2013. Tingkat Keterampilan Teknik Dasar Bermain Futsal Peserta Ekstrakurikuler Futsal SMA dan SMK Yayasan Piri Daerah Itimewah
Yogyakarta. Yogjakarta: Universitas Negeri Yogjakarta.

Prastya, Rizki Dwi. 2005. Manajemen Ekstrakurikuler Futsal SMA Negeri 4 Yogyakarta Tahun Aaran 2015. Yogjakarta: Universitas Negeri Yogjakarta.

Nasrudin Roni. 2010. Pengaruh Partisipasi Siswa Dalam Kegiatan Ekstrakurikuler Terhadap Motif Berprestasi Siswa SMK N 2 Garut. Skripsi: UPI Bandung.

Sucipto. 2000. Sepakbola Latihan dan Strateg. Jakarta: Jaya Putra.

Sugiyono. 2006. Memahami Penelitian Kuantitatif. Bandung: ALFABETA.

Suharno HP. 1984. Dasar-dasar Permainan Bolavoli, hal 12. Yogyakarta: FPOK IKIP Yogyakarta.

Sukadianto. 2005. Teori dan Metodologi Melatih Fisik. Yogyakarta : FIK UNY.

Tenang, Jhon D. 2008. Mahir bermain futsal. Jakarta : DAR Mizan.

Yudianto, Lukman. 2009. Teknik Bermain Sepak Bola dan Futsal. Visi 7 